\title{
POMIRTINĖS TEISMO PSICHIATRIJOS EKSPERTIZĖS - IŠŠŪKIS TEISMO PSICHIATRUI
}

\author{
Vaiva Martinkiené $\dot{\mathbf{e}}^{1,2}$ \\ ${ }^{1}$ Valstybine teismo psichiatrijos tarnyba prie Sveikatos apsaugos ministerijos, \\ ${ }^{2}$ Vilniaus universiteto Medicinos fakulteto Psichiatrijos klinika
}

Raktažodžiai: pomirtinè teismo psichiatrijos ekspertizè, testamentinis veiksnumas.

\begin{abstract}
Santrauka
Pomirtinès teismo psichiatrijos ekspertizès metu teismo psichiatrai ekspertai retrospektyviai vertina asmens psichikos būseną testamento pasirašymo metu. Šiose ekspertizèse teismo ekspertai dažnai turi vertinti senyvo amžiaus asmenų, sergančių sunkiomis somatinèmis ligomis, būseną ir ịvertinti vidaus ligų poveikị psichikos būklei testamento pasirašymo metu. Tyrimo metu išanalizuoti Valstybinès teismo psichiatrijos tarnybos (VTPT) prie SAM 2016-2018 metais atliktų 117 pomirtinių teismo psichiatrijos ekspertizių duomenys. Tirtų asmenų, surašiusių testamentus, amžiaus vidurkis buvo $78 \mathrm{~m}$. Tyrimo metu pastebėta, kad vyrai testamentus sudare būdami apie $10 \mathrm{~m}$. jaunesni, nei moterys: vyrų amžiaus vidurkis - $74 \mathrm{~m}$., moteru $-82 \mathrm{~m}$. Nustatyta, kad net 42 proc. atvejų testamentus asmenys pasirašè likus mènesiui ar keletui dienų iki mirties. Tyrimo metu išsiaiškinta, kad beveik pusę notariškai patvirtintų testamentų pasirašè asmenys, būdami testamentinio neveiksnumo būsenoje dèl turètų psichikos sutrikimų. Pomirtinès teismo psichiatrijos ekspertizès metu dažnai nebūna asmens psichikos būsenos įvertinimo ikitestamentiniu laikotarpiu, o testamento pasirašymo metu dauguma testatorių serga sunkiomis somatinèmis ligomis: lètine smegenų išemija, onkologinèmis ligomis, cukriniu diabetu su komplikacijomis, kepenų ar inkstų nepakankamumu, Parkinsono liga ir kitomis neurodegeneracinemis ligomis. Tyrimo duomenys parode, kad teismo psichiatras privalo turèti gilias ne tik psichiatrijos, bet ir somatinių ligų sukeltų psichikos sutrikimų ịvertinimo žinias.
\end{abstract}

\section{Ivadas}

Pomirtinès teismo psichiatrinès ekspertizès yra sudètin- giausios, nes yra būtina ịvertinti mirusio asmens psichikos būseną retrospektyviai juridinio sandorio ar testamento sudarymo metu. Ypatingą vertę pomirtinëje ekspertizèje, vertinant testamentini veiksnumą, turi ligos istorijos ir kiti medicininiai dokumentai, dalykiniai ar asmeniniai užrašai, asmeninè korespondencija, dienynai ir užrašai, kurie gali tiesiogiai atspindèti testatoriaus psichikos ypatumus ir suteikti žinias, pakankamas motyvuotai testamentinio veiksnumo įvertinimo išvadai pateikti. Prisiekusių teismo posėdžio metu liudytojų (sutuoktinio, draugų, giminaičių, kolegų) parodymai gali suteikti papildomą informaciją, tačiau liudijimai dažnai būna prieštaringi ir neapibrèžti laike.

Testamentas gali būti ginčijamas, kai yra:

1) įtarimas, kad testatorius buvo testamentinio neveiksnumo būklèje, sudarydamas testamentą;

2) įtarimas, kad testamento sudarymo metu buvo neleistino poveikio testatoriui požymiai iš vieno ar kelių asmenų [1].

Teisine testamentinio veiksnumo sąvoka suprantama kaip testatoriaus pakankamų psichikos gebejjimų buvimas, kad jis galètų:

1) suprasti testamento esmę;

2) suprasti ir atgaminti iš atminties savo paties būklès ir turimo turto pobūdị;

3) atsiminti savo gyvus artimuosius ir visiškai suprasti santykius su jais;

4) suvokti savo santykị su sutuoktiniu, vaikais ir su tais, kieno interesus palies testamentas [1].

Asmens, sudariusio juridinị sandorị arba testamentą, retrospektyvinis ekspertinis psichikos būsenos įvertinimas remiasi tų pačių esminių - medicininio ir juridinio - kriterijų nustatymu. Teismo psichiatras ekspertas ịvertina visą pateiktą medžiagą, kurią pomirtinès ekspertizès metu sudaro: bylos dokumentai, mirusiojo asmens rašytiniai dokumentai, padaryti artimu testamento/sandorio sudarymui laiku, liudininkų parodymai, atspindintys to laikotarpio asmens elgsenos, bendravimo ir funkcionavimo ypatumus, medicinine dokumentacija. Teismo psichiatrui ekspertui tenka 


\section{0}

atsižvelgti ị visą eilę papildomų aplinkybių, kurios galèjo turèti ịtakos išreikšti asmens valią: somatinẻ būklè, sandorio sudètingumas, sandorio surašymo vieta, buvusių testatoriaus moralinių-vertybinių nuostatų atitikimas nurodomai valiai, testatoriaus priklausomumas ir jo poveikio galimybe, testatoriaus emocinių santykių su artimaisiais pobūdis, eilè kitų šalutinių faktorių [2].

Neleistinos įtakos tyrimo atvejais JAV teismuose psichiatrui ekspertui pavedama įvertinti:

1) nenatūralų, netaisyklingą išsireiškimą testamente;

2) teiginius, prieštaraujančius prieš tai buvusiam ir po to sekusiam asmens valios pareiškimams;

3) santykius tarp testatoriaus ir paveldetojo, kurie sudaro galimybę kontroliuoti testatoriaus valios išreiškimą;

4) psichinę ar fizinę testatoriaus būseną, kuri palengvina jo laisvos valios paveikimą;

5) aktyvų paveldètojo vaidmenį testamento atsiradimo (sudarymo) procese;

6) nepagrịstą paveldètojo praturtèjimą pagal testamento turini;;

7) pasitikèjimo santykị tarp testatoriaus ir paveldètojo.

Šie indikatoriai yra tiriami daugumoje JAV valstiju teismų, vertinant asmens testamentini veiksnumą.

Neleistinos įtakos įrodymui tarnauja tokios aplinkybès:

1) testamento atsiradimui aktyvų vaidmenį turèjo suinteresuoti asmenys;

2) suinteresuotas asmuo buvo pasitikèjimo santykyje su testatoriumi (artima giminyste, konsultantas, slaugantis asmuo);

3) suinteresuota pusė ženkliai praturtejo testamento dẻka.

Yra nustatyta keletas galimos neleistinos įtakos požymių - indikatorių:

1) testamente keisti, nenatūralūs, neįprasti išsireiškimai;

2) testamentas, pakeičiantis prieš tai buvusị testamentą;

3) paveldètojas buvo tokiuose santykiuose, dèl kuriu turejjo galimybę kontroliuoti testatoriaus būklę;

4) psichinè ar fizinè testatoriaus būklè, kuri palengvina jo laisvos valios nuslopinimo galimybę;

5) paveldètojas aktyviai dalyvavo testamento sudarymo procese;

6) žymus nepagrịstas paveldetojo praturtèjimas testamento dèka;

7) pasitikèjimo santykiai, buvę tarp paveldètojo ir testatoriaus [2].

Testamentinio veiksnumo vertinimas pomirtinès teismo psichiatrijos ekspertizès metu. Psichikos sutrikimas gali, tačiau ne visuomet, tiesiogiai paveikti testamentini veiksnumą.

İvertinama tai, kad senatvè ar užmaršumas, charakterio keistumai, periodiškai pasireiškiantis pasimetimas, lengvas protinis nepilnavertiškumas patys savaime dar nèra pakankami, kad jais būtų grindžiami teismo sprendimai, kad testatorius yra praradęs testamentinị veiksnumą [3].

Dèl psichikos sutrikimo ir neleistinos įtakos ryšio. Reikia žymiai mažiau pastangų padaryti įtaką ar kontroliuoti testamentą asmens, kurio funkciniai gebėjimai buvo rimtai susilpnėję dèl psichikos sutrikimo ar dẻl somatinès ligos, kuri sutrikdo psichikos veiklą. Esant testatoriaus kompetencijos nepakankamumui ar intelekto sumenkèjimui, gali būti keliamas klausimas dèl neleistinos įtakos testatoriui darymo. Retrospektyviai vertinant neleistinos įtakos buvimą svarbu atsakyti ị klausimus:

1) ar testatorius testamento sudarymo metu ar iki to sirgo psichikos sutrikimu ar somatine liga, padidinančia įtaigumą neleistinai įtakai?

2) ar tuo laikotarpiu buvo kokie nors asmenybès ypatumai, socialinès ar artimos aplinkos faktoriai, kurie tam tikru laipsniu galejo pasitarnauti neleistinos įtakos panaudojimui $[2,3]$ ?

Daugelio psichiatru patirtis patvirtina, kad bet koks sunkus psichikos ar somatinis sutrikimas, sukeliantis priklausomybę nuo asmenų, užtikrinančių slaugą, padidina asmens pasidavimą įtakai.

Susirgimai, sumažinantys kritikos gebejjimą (maniakinè ar hipomaniakinè būsena), sutrikdantys realybès suvokimą (kliedesinis sutrikimas ar šizofrenija, sutrikusi orientacija), ženkliai sutrikdantys savarankiškumą (būtina slauga) tikètinai sumažina asmens sugebejjimą pasipriešinti ịtakai net ir nesant reikšmingo priklausomybès ryšio $[3,4]$.

Pomirtinė teismo psichiatrijos ekspertizè pradinès silpnaprotystės stadijos atveju. Ekspertinė praktika parodo, kad pomirtinès ekspertizès dažniausiai paskiriamos senyvo amžiaus žmonėms - vyresniems kaip 60 ar 70 metų, turintiems tam tikrus organinius galvos smegenų pakitimus dažniausiai sąlygotus smegenų kraujagyslių aterosklerozės, kurie sukelia protinès veiklos - intelektinius ir atminties - sutrikimus.

Ypač sudètinga atlikti ekspertini pažintinių sugebèjimų vertinimą pradinėse demencijos stadijose.

Ankstyvose smegenų kraujagyslių aterosklerozės stadijose asmuo dar vykdo ịprastą ūkinę veiklą, turi tam tikras galimybes ir psichikos resursus, tačiau dèl turimų kognityvinių pakitimų jo teisiniuose sprendimuose gali būti reikšmingu klaidų ir jis gali sudaryti neteisingus sandorius ar sutartis $[5,6]$. Būtina atsižvelgti, ar sudarytas sandoris/testamentas atitiko asmens interesus, buvo nesudètingas savo turiniu, atspindejo ankstesnius tiriamo asmens emocinius ryšius ir santykius su artimaisiais $[7,8]$.

Būtina ịvertinti ir tokias aplinkybes, kad ị naują situaciją, naują nepažistamą aplinką asmuo su kognityviniais poky- 
čiais gali reaguoti staigiu psichinès būsenos pablogejjimu, pasimetimu, dezorientacija, psichomotoriniu sujaudinimu, baime, pažintinių funkcijų sutrikimu, taip pat ir tam tikromis psichozinèmis apraiškomis $[3,9,10]$.

Ankstyvose smegenų kraujagyslių aterosklerozės stadijose pasireiškia greitas protinès veiklos išsekimas, padidèjęs užmaršumas, nuovargis, greitesnis dèmesio išsekimas, nesugebejjimas sutelkti ir išlaikyti dèmesio ilgesniam laikui, esant psichinei įtampai, sumenkèjęs mąstymo produktyvumas, kas akivaizdžiai sutrikdo asmens ịprastą kasdienę veiklą. Asmenims, turintiems ankstyvos stadijos smegenų kraujagyslių aterosklerozès sąlygotą silpnaprotystę, dažnai pasireiškia specifinis atminties sutrikimas: pirmiausia sutrinka naujos informacijos priemimas, isiminimas ir atgaminimas, o senesni, anksčiau ịsiminti dalykai, yra geriau atsimenami ir atgaminami. Kraujagyslinèms lètinèms bei ūmioms demencijoms būdingas psichikos funkcijų pažeidimų netolygumas. Tokių būklių ịvertinimas sukelia nemažai sunkumų. Seniau išmokti elgesio stereotipai išlieka ilgiau, tačiau sutrinka naujos informacijos suvokimas ir ịsiminimas $[4,11]$.

Ekspertinio vertinimo metu būtina atkreipti dèmesị ị skirtingą ịvairios etiologijos demencijų klinikinį vaizdą.

Kraujagyslinèms lètinèms bei ūmioms demencijoms būdingas psichikos funkcijų pažeidimų netolygumas. Tokių būklių ịvertinimas sukelia nemažai sunkumų. Neretai asmuo ilgą laiką išsaugo turètas išorines elgesio-moralines savybes, nors jau būna pažeistos jo pažintinès funkcijos: atmintis, dèmesys, išmokimas.

Frontotemporalinei demencijai būdingi ankstyvi asmeninès ir socialinès savimonès sutrikimai (šiurkštus humoras, elgesio disinhibicija, higienos ir moralès normų nepaisymas) - t. y. pirmiausiai nukenčia asmenybe ir asmeninių-socialinių santykių sritys, tačiau kognityviniai gebẻjimai ilgiau išlieka nepakitę.

Semantinès demencijos variantui būdinga anksčiausiai sutrikęs žodžių suvokimas ir vizualinis atpažinimas (veidų, objektų), tačiau aktyvi kalba išlieka sklandi ir pradinèje stadijoje atminties sutrikimu nestebima.

Pirminès progresuojančios afazijos demencijai būdingas pirminis kalbos ekspresijos sutrikimas ir kalbos struktūros praradimas, kurị laiką išliekant nepakitusioms kognityvinèms funkcijoms.

Demencijai dèl Alzheimerio ligos ankstyvoje stadijoje būdingi dèmesio ir fiksacinès atminties sutrikimai, tačiau ilgiau išlieka nepakitęs savo nuosavybės suvokimas ir anksčiau ịgyta patirtis.

Demencijai sergant Hantingtono chorejja būdingas ankstyvas asmenybės sutrikimas (asmenys tampa pikti, priekabūs, dirglūs), dèl to pirmiausia sutrinka asmeniniai-socialiniai ryšiai, o kognityvinès funkcijos kurị laiką išlieka nepakitusios.
Demencijai su Lewy kūneliais būdinga pradžioje svyruojantis dèmesio ir atminties lygis, regos haliucinacijos, ryškiai sutrikę erdviniai-konstrukciniai gebejjimai, dèl to pirmiausia sutrinka savitvarkos veiksmai [12].

Pomirtinė teismo psichiatrijos ekspertizė onkologinių ligų atveju. Vertinant onkologine liga sirgusio asmens psichikos būseną, analizuojami onkologinèse gydymo ịstaigose surašyti medicininiai dokumentai. Juose detaliai aprašoma somatinè būklè, tačiau dažniausiai labai menkai atspindima ar visiškai neatspindima asmens psichikos būklè ir jos kaita. Teismo psichiatras ekspertas pomirtineje ekspertizejje turi remtis medicininiuose dokumentuose aprašytais somatinès būklès ypatumais, išsekimo ar véžinès intoksikacijos aprašymais, t. y. netiesiogine informacija, liudijančia apie buvusị psichikos būklès sutrikimą ir/ar kognityvinį sutrikimą.

Pomirtinèse ekspertizèse pastebima, kad neretai sandorius/testamentus asmenys sudaro būdami terminalinėse onkologinès ligos stadijose, kelias dienas prieš mirtị. Tokioje būklèje asmenims pasireiškia gausi, polimorfiška psichikos sutrikimų simptomatika.

Sunkaus onkologinio susirgimo ir vėžinès intoksikacijos būsenoje galimi ženklūs sąmoningumo, kritiškumo ir prognostinių gebẻjimų sutrikimai. Išsekimo ar vėžinès intoksikacijos būsenose asmenys praranda gebejimą iki galo suprasti situaciją, aplinkybes, kritiškai vertinti sandorio esmę, numatyti galimas pasekmes, ịvertinti savo veiksmų reikšmę, gebejjimą gerai valdyti savo veiksmus, veikti savarankiškai, tikslingai, kryptingai išreikšti ir realizuoti savo tikrają vidinę valią. Tyrimų duomenimis, apie 79 proc. atvejų asmenys, sergantys onkologine liga, turëjo psichikos sutrikimų [13].

Onkologini susirgimą neretai lydi depresija. Daug atidumo ekspertiniame vertinime reikalauja sunki depresinè simptomatika, dèl kurios yra galimas asmens itakojimas, pasyvus paklusnumas aplinkinių prašymams ar reikalavimams. Labai sunkios, vitalinès depresijos atveju galimi sąmonès susiaurejjimo, kokybinio pakitimo epizodai, dèl kurių sutrinka asmens mąstymo, kritinio vertinimo ir kryptingos veiklos gebejimai $[4,13]$.

Vèlyvose onkologinès ligos stadijose sutrinka kognityvinès funkcijos: dèmesys, atmintis, nuovokumas, orientacija, pasireiškia greitas protinès veiklos išsekimas, vangumas, sulètejjimas, pasyvumas dèl sunkios bendros būklès. Labai sunki somatinè būklè nulemia tai, kad asmuo būna pasyvus, atsiribojęs ir neretai tik pasyviai, formaliai ir mechaniškai pritaria jam išsakomiems teiginiams, tampa visiškai abejingas tiek situacijai, tiek perspektyvai. Esant sunkiai somatinei būsenai, věžinei intoksikacijai, skausminiam sindromui bei narkotinių analgetikų poveikiui dažnai pasireiškia tam tikro laipsnio sąmoningumo sutrikimas. Terminalinèje onkologinio susirgimo būklëje netenkama kritinio vertinimo sugebejjimo, 


\section{2}

pasireiškia pasyvumas, ịtaigumas, kartojasi psichoziniai/ delyriniai epizodai, tokioje būklèje asmenys nèra pajègūs suvokti savo veiksmų esmès ir jų valdyti. Testamento surašymas ar testamentinès valios pakeitimas terminalinèje stadijoje savaitę ar keletą dienų prieš mirtị dažniausiai yra inicijuojamas kitų asmenų, nes testatoriaus būklè jau neleidžia jam pačiam aktyviai atlikti jokių veiksmų ir sukuria išskirtinio priklausomumo situaciją dèl būtinos elementarios buitinès, slaugos ir gydymo pagalbos [2, 13].

Pomirtinès teismo psichiatrijos ekspertizès sunkių vidaus ligų atveju. Pomirtinėse ekspertizèse teismo psichiatrams tenka sunkus uždavinys tiksliai kvalifikuoti atskiroms sunkioms somatinėms ligoms ar jų komplikacijų būsenoms būdingus psichikos ir/ar kognityvinių sutrikimų požymius. Sunkios somatinès ligos atveju neretai pasireiškia tam tikri sąmonès sutrikimai, kurie gali būti tęstiniai ir trumpalaikiai, ryškesni ir mažiau ryškūs: trumpi sąmoningumo nutrūkimai (obnubiliacijos), pastovus sąmonès deficitas/sąmonès pritemimas, kokybinès sąmonès sutrikimo būsenos (delyras, prieblandinès būsenos ir kt.) [13-15].

Teismo psichiatrai ekspertai pomirtinėse ekspertizèse dažniausiai turi vertinti šias sunkias somatines būkles:

1) lètinis ar ūmus širdies nepakankamumas, miokardo infarktas, plaučių tromboembolija;

2) arterijų aterosklerozè ir lètinè smegenų išemija;

3) hipertoninė liga ir smegenų insultai;

4) inkstų ligos su jas lydinčiu inkstų nepakankamumu;

5) cukrinis diabetas su komplikacijomis;

6) piktybiniai navikai, lydimi ryškaus skausminio sindromo ir véžinès intoksikacijos;

7) galvos smegenų progresuojančios neurodegeneracinès ligos.

Sunkioms somatinèms būklëms būdingi psichikos sutrikimai:

1) nespecifiniai, neuroziniai reiškiniai;

2) psichoziniai simptomai;

3) kognityvini pažeidimą atspindintys simptomai;

4) sąmonès sutrikimą atspindintys ịvairaus sunkumo simptomai $[13,16]$.

Teismo psichiatrijos pomirtinès ekspertizès yra susijusios su informacijos ribotumu, pateikiamų medicininių dokumentų skurdumu ir nepakankamumu, nesant juose gydytojų psichiatrų irašų, todèl ekspertai, remdamiesi tik vidaus ligų gydytojų įrašais, kartais gali pateikti tik prielaidinio pobūdžio išvadas.

Darbo tikslas: apžvelgti mokslinès literatūros duomenis apie testamentinio veiksnumo îvertinimo bei pomirtinių teismo psichiatrijos ekspertizių atlikimo ypatumus bei įvertinti VTPT prie SAM 2016-2018 m. atliktų pomirtinių teismo psichiatrijos ekspertizių bendruosius (amžius, lytis, gyvenamoji vieta) ir specialiuosius (testamento sudarymo laikas, notarinis patvirtinimas, ekspertinès išvados) duomenis, siekiant išryškinti pomirtinių teismo psichiatrijos ekspertizių ypatumus.

\section{Tyrimo objektas, metodai ir gauti rezultatai}

Tyrimo metu buvo apžvelgti specialiosios literatūros šaltiniai, naudojant elektronines duomenų bazes: Medline, PubMed, Research gate. Atlikta VTPT prie SAM 2016-2018 $\mathrm{m}$. pomirtinių teismo psichiatrijos ekspertizių duomenų analizè pagal specialiai parengtą duomenų atrankos klausimyną.

VTPT prie SAM duomenimis, nuo $2007 \mathrm{~m}$. stebeta didejjanti pomirtinių ekspertizių santykinè dalis nuo visų atliekamų ekspertizių skaičiaus, kasmet buvo atliekama daugiau nei 50 tokios rūšies ekspertizių. Pastaraisiais metais stebima skiriamų pomirtinių teismo psichiatrijos ekspertizių mažèjimo tendencija - kasmet paskiriama vidutiniškai 35 šios rūšies ekspertizès.

Bendrieji duomenys. VTPT 2016-2018 metų laikotarpiu buvo atlikta 117 pomirtinių teismo psichiatrijos ekspertizių civilinèse bylose. Jų skaičius kito: $2016 \mathrm{~m}$. buvo atliktos 54, o 2018 m. - 28.

Pomirtinèse ekspertizėse tirtų asmenų amžiaus vidurkis buvo nevienodas: bendras amžiaus vidurkis vyrams - $74 \mathrm{~m}$., moterims $-82 \mathrm{~m}$., visų pomirtinėse ekspertizèse tirtų asmenų amžiaus vidurkis, surašant testamentus, $78 \mathrm{~m}$. (1 lentelè).

1 lentelè. Asmenų amžiaus vidurkis.

\begin{tabular}{|l|c|c|}
\hline Metai & Vidutinis vyrų amžius & Vidutinis moterų amžius \\
\hline 2016 & $73 \mathrm{~m}$. & $80 \mathrm{~m}$. \\
\hline 2017 & $69 \mathrm{~m}$. & $78 \mathrm{~m}$. \\
\hline 2018 & $79 \mathrm{~m}$. & $89 \mathrm{~m}$. \\
\hline
\end{tabular}

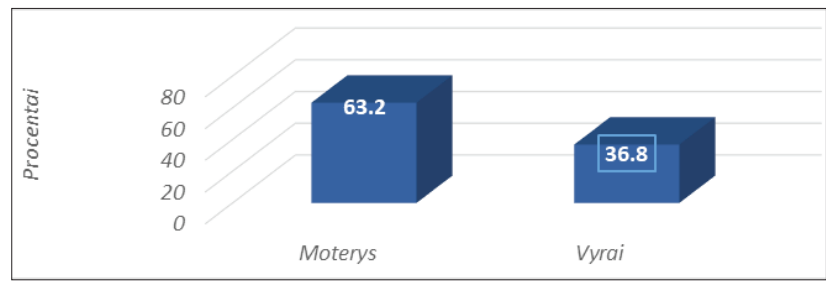

1 pav. Lytis.

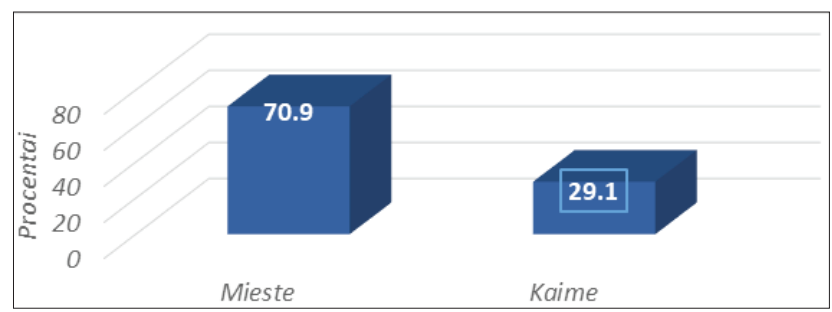

2 pav. Gyvenamoji vieta. 
Duomenys parodè, kad surašiusių testamentus asmenų amžiaus vidurkis kito, tačiau pastebėta, kad vyrai vidutiniškai $10 \mathrm{~m}$. anksčiau sudarè testamentus. Tai atitinka šiuo metu Lietuvoje esanti $10 \mathrm{~m}$. skirtumą tarp vyrų ir moterų vidutinès gyvenimo trukmès.

Iš visų atliktų pomirtinių teismo psichiatrijos ekspertizių moterys sudare $2 / 3$ atvejų. Pomirtinėse ekspertizèse tirta: moterys $-63,2$ proc. $(\mathrm{N}=71)$, vyrai $-36,8$ proc. $(\mathrm{N}=43)(1$ pav. $)$.

Sandorius sudariusieji $2 / 3$ atvejų gyveno mieste $-70,9$ proc. $(\mathrm{N}=83)$, tik $1 / 3$ dalis gyveno kaime - 29,1 proc. $(\mathrm{N}=34)$ (2 pav.).

Testamento sudarymo laikas. Dauguma testamentus sudariusių asmenų juos sudare prieš keletą metų iki mirties - 59 proc. $(\mathrm{N}=69)$ atvejų, prieš keletą mènesių iki mirties -32 proc. $(\mathrm{N}=37)$, vieną ar kelias dienas prieš mirti - 9 proc. $(\mathrm{N}=11)$. Testamentai, sudaryti sergančių asmenų keletą mėnesių/dienų iki mirties, sudarè beveik pusę visų tirtų atvejų- 42 proc. $(\mathrm{N}=48)$ ( 3 pav.).

Notarinis patvirtinimas. Analizuojant testamento pasirašymo aplinkybes, nustatyta, kad tik 7,7 proc. atvejų ( $\mathrm{N}=9$ ) testamento netvirtino notaras - buvo pateiktas rašytinis testamentas arba ji patvirtino gydymo įstaigoje gydytojas. Visi kiti testamentai net 92,3 proc. $(\mathrm{N}=108)$ buvo patvirtinti notaro.

Iš atliktų 117 pomirtinių teismo psichiatrijos ekspertizių net 78 procentais atvejų $(\mathrm{N}=90)$ nebuvo asmens būsenos psichiatrinio îvertinimo iki testamento sudarymo (2 lentelè).

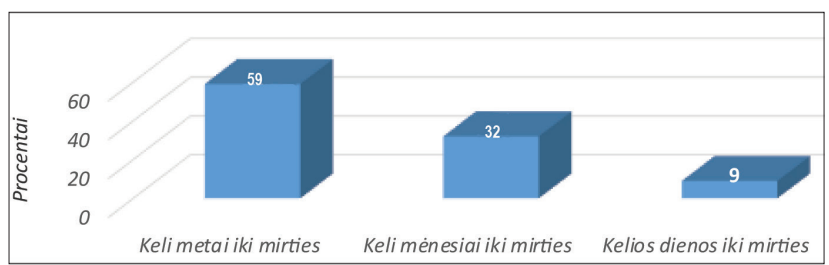

3 pav. Testamento sudarymo laikas.

2 lentelè. Nebuvo psichikos būsenos įvertinimo iki testamento sudarymo.

\begin{tabular}{|l|c|c|}
\hline Metai & Atvejai & Procentai \\
\hline 2016 & 54 pomirtinių ekspertizių & 72 proc. $(\mathrm{N}=39)$ \\
\hline 2017 & 35 pomirtinių ekspertizių & $\mathbf{8 0}$ proc. $(\mathrm{N}=28)$ \\
\hline 2018 & 28 pomirtinių ekspertizių & $\mathbf{8 2}$ proc. $(\mathrm{N}=23)$ \\
\hline
\end{tabular}

3 lentelè. Išvados.

\begin{tabular}{|l|c|c|c|}
\hline Metai & $\begin{array}{c}\text { Kategoriškos } \\
\text { išvados }\end{array}$ & $\begin{array}{c}\text { Kategoriškos teigia- } \\
\text { mos išvados }\end{array}$ & $\begin{array}{c}\text { Prielaidinės } \\
\text { išvados }\end{array}$ \\
\hline $\mathbf{2 0 1 6}$ & $\begin{array}{c}\mathbf{8 3} \text { proc. } \\
(\mathrm{N}=45 \text { iš } 54)\end{array}$ & $2 / 3$ & $\begin{array}{c}\mathbf{1 7} \text { proc. } \\
(\mathrm{N}=9 \text { iš } 54)\end{array}$ \\
\hline $\mathbf{2 0 1 7}$ & $\begin{array}{c}\mathbf{6 3} \text { proc. } \\
(\mathrm{N}=22 \text { iš } 35)\end{array}$ & $3 / 4$ & $\begin{array}{c}\mathbf{3 7} \text { proc. } \\
(\mathrm{N}=14 \text { iš } 35)\end{array}$ \\
\hline $\mathbf{2 0 1 8}$ & $\begin{array}{c}\mathbf{7 5} \text { proc. } \\
(\mathrm{N}=21 \text { iš } 28)\end{array}$ & $3 / 4$ & $\begin{array}{c}\mathbf{2 5} \text { proc. } \\
(\mathrm{N}=7 \text { iš } 28)\end{array}$ \\
\hline
\end{tabular}

Ekspertinès išvados. Teismo psichiatras ekspertas, atlikęs pomirtinę teismo psichiatrijos ekspertizę, gali duoti:

a) kategorišką teigiamą išvadą (asmuo galèjo dèl savo psichinès būsenos suprasti savo veiksmų esmę ir juos valdyti);

b) kategorišką neigiamą išvadą (negalèjo);

c) prielaidinę teigiamą (tikètinai galèjo);

d) prielaidinę neigiamą (tikètinai negalèjo);

e) atsisakyti duoti ekspertinę išvadą (kai tam nepakanka faktinių medicininių duomenų apie asmens sveikatos būklę tiriamu laikotarpiu).

VTPT tyrimo duomenys. Prielaidinès teigiamos išvados kasmet sudarè pusę prielaidinių išvadų (4 pav.).

Pirminès pomirtinès ekspertizès sudare 83 proc. $(\mathrm{N}=97)$, 17 proc. $(\mathrm{N}=20)$ atvejų atliktos pakartotinès pomirtinès ekspertizès.

Tyrimo metu nustatyta: pomirtinių teismo psichiatrijos ekspertizių išvados rodo, kad beveik pusės notariškai patvirtintų testamentų pasirašymo metu testatoriai turejo psichikos sutrikimų, dèl kurių jie buvo testamentinio neveiksnumo būsenoje (5 pav.).

Somatinès būklès, tirtos pomirtinèse ekspertizèse. Analizuota, kokios somatinès būsenos buvo vertinamos pakartotinių pomirtinių ekspertizių metu. Išsiaiškinta, kad daugumoje atvejų tai buvo sudètingas keleto sunkių somatinių ligų ir jų komplikacijų derinys, nesant psichiatrinio asmens ịvertinimo ikitestamentiniu laikotarpiu, stokojant aiškios informacijos apie psichinę asmens būklę testamento sudarymo metu.

Sudètingų somatinių būklių, tirtų pomirtinès teismo psichiatrijos ekspertizès metu, pavyzdžiai:

Kepenų cirozė, portinè hipertenzija, splenomegalija, ascitas, hepatinè encefalopatija, hipertenziné liga su krizèmis - šiuo atveju pakartotinès pomirtinès ekspertizès metu

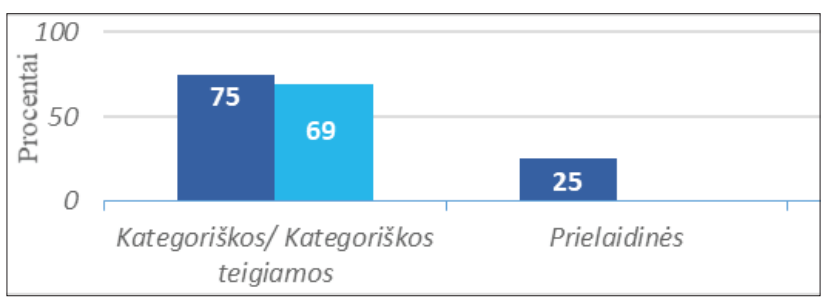

4 pav. 2016-2018 metais pomirtinėse ekspertizèse duotos išvados.

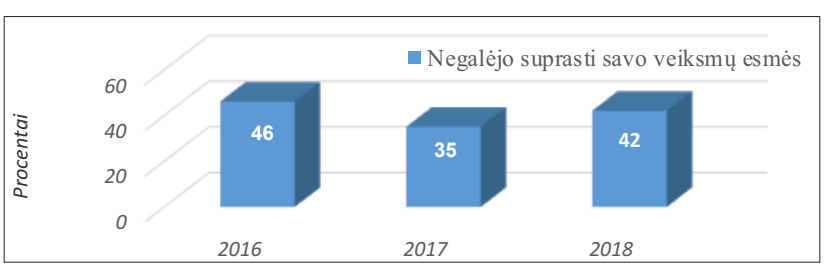

5 pav. Testamentinis neveiksnumas. 
ekspertai nenustatè buvus psichikos sutrikimo testamento sudarymo metu.

Lètinè galvos smegenų išemija ir encefalopatija, išeminiai paroksizmai, išeminis insultas (tranzitorinis), žarnyno karcinoma su metastazèmis plaučiuose - pakartotinès pomirtinès ekspertizès metu ekspertai nustatė testamento sudarymo metu buvus adaptacijos sutrikimą.

Išeminė širdies ir galvos smegenų liga, lètinè smegenų išemija, širdies nepakankamumas 3-4 f. kl., mazginè struma, hipotireozé, kepenų ir inkstų policistozè, pilvo aortos aneurizma - pakartotinès pomirtinès ekspertizès metu ekspertai nustate testamento sudarymo metu buvus organini emocinio labilumo sutrikimą.

Dekompensuotas CD, diabetinè polineuropatija ir encefalopatija, nefropatija, būkle po inksto transplantacijos, inkstų funkcijos nepakankamumas, uremija, lètinè anemija - pakartotinés pomirtinés ekspertizès metu ekspertai nustaté diagnozę: kiti psichikos sutrikimai dèl smegenų pažeidimo, disfunkcijos ir somatinès ligos F06.8.

Smegenų arterijų aterosklerozé, lètinė smegenų išemija ir encefalopatija, miokardo infarktas, pasikartojantys smegenų išemijos epizodai, širdies nepakankamumas 3-4 f. kl., lètiné anemija, lètinis autoimuninis tiroiditas, lètinè dekompensuota hipotireozé, sunki forma, abipusė katarakta, aklumas - pakartotinès pomirtinès ekspertizès metu ekspertai nustate diagnozę: mišri kraujagyslinė demencija F01.3.

Tyrimo metu nustatytos pomirtinèse ekspertizèse dominuojančios sunkios somatinès būsenos (4 lentelè).

\section{Išvados}

Atlikto tyrimo duomenys parodè, kad pomirtinèse teismo psichiatrijos ekspertizèse teismo psichiatrai ekspertai turi

4 lentelè. Somatinès būsenos.

\begin{tabular}{|l|c|}
\hline Somatinės būsenos & Atvejai \\
\hline $\begin{array}{l}\text { Galvos smegenų išemijos būsenos su lydinčiomis } \\
\text { komplikacijomis-insultais bei encefalopatijos dia- } \\
\text { gnozemis }\end{array}$ & $\begin{array}{c}\mathbf{4 9 , 5} \text { proc. } \\
(\mathrm{N}=58)\end{array}$ \\
\hline $\begin{array}{l}\text { Onkologiniai susirgimai su skausminiu sindromu, } \\
\text { intoksikacija }\end{array}$ & $\begin{array}{c}\mathbf{2 0 , 5} \text { proc. } \\
(\mathrm{N}=24)\end{array}$ \\
\hline $\begin{array}{l}\text { Cukrinis diabetas su komplikacijomis: polineuro- } \\
\text { patijos, nefropatijos ir encefalopatijos diagnozemis }\end{array}$ & $\mathbf{7 , 7}$ proc. \\
$(\mathrm{N}=9)$
\end{tabular}

atlikti labai sudètingą duomenų analizę.

Ekspertinį vertinimą apsunkina:

1. Tiriamų asmenų senyvas amžius (vidurkis yra apie 78 m.) ir jų turimos sunkios somatinès ligos.

2. Apie puse tiriamujų testamentus sudaro paskutiniaisiais gyvenimo mènesiais/dienomis.

3. Ekspertui tenka ịvertinti beveik visuomet $(92,3$ proc. atvejų) notariškai patvirtintą testamentą sudariusio asmens būseną, kas sukelia papildomus prieštaravimus.

4. Net $2 / 3$ atvejų nebūna asmens psichikos būsenos ịvertinimo iki testamento sudarymo.

5. Ekspertas turi analizuoti sunkių somatinių ligų ir jų komplikacijų ịtaką asmens psichikos būsenai.

6. Sudètingi, neretai prieštaringi arba labai skurdūs medicininiai duomenys leidžia tik apie 75 proc. atvejų pateikti kategoriškas ekspertines išvadas, o kitais atvejais yra daromos prielaidinès išvados.

Tyrimo duomenys parodè, kad pomirtinè teismo psichiatrijos ekspertize yra didžiulis profesinis iššūkis teismo psichiatrui, todèl teismo psichiatras privalo turèti išsamias ne tik psichiatrijos, bet ir somatinių ligų sukeltų psichikos sutrikimų įvertinimo žinias.

\section{Literatūra}

1. Ed. by Gunn J, Taylor PJ (ed.). Forensic Psychiatry (sec. ed.), New York 2014.

2. Puri B, Treasaden IH (ed.). Forensic Psychiatry: fundamentals and clinical practice, Taylor \& Francis, 2018. https://doi.org/10.1201/9781315380797

3. Eastman N, Adshead G, Fox S, Latham R, Whyte S. Forensic Psychiatry. Oxford University Press, 2012.

https://doi.org/10.1093/med/9780199562824.001.0001

4. Dembinskas A. Psichiatrija. Vilnius, 2003.

5. Li M, Meng Y, Wang M, Yang S, Wu H. et al. Cerebral grey matter volume reduction in subcortical vascular mild cognitive impairment patients and subcortical vascular dementia patients, and its relation with cognitive deficits. Brain and Behavior 2017. https://doi.org/10.1002/brb3.745

6. Sperling RA, Aisen PS, Beckelt LA. et al. Toward defining the preclinical stages of Alzheimer's disease: recommendations from the National Association Institute on Aging-Alzheimer's Association workgroups on diagnostic guidelines for Alzheimer's disease. Alzheimer's Dementia 2011; 7:280-292.

7. Tahaka H, Hashimoto M, Fukuhara R et al. Relationship between dementia and psychological symptoms in early-onset Alzheimer's disease. Psychogeriatrics 2015;15:242-247.

https://doi.org/10.1111/psyg.12108

8. Irish M, Piolino P. Impaired capacity for prospection in the dementias - theoretical and clinical implications. British Journal of Clinical Psychology 2016; 1:49-68.

https://doi.org/10.1111/bjc. 12090 
9. Droper B, Withall A. Young onset dementia. Internal Medicine Journal 2016; 7:779-786. https://doi.org/10.1111/imj.13099

10. Bayard S, Jacus JP, Raffard S, Gely-Nargeot M Ch. Concious knowledge and decision making under ambiguity in mild cognitive impairment and Alzheimer's disease. Alzheimer's Dis Assoc Disord 2015; 19:4357-359.

11. Whalley LJ, Breitneris C.S.J. Demencija. Vilnius, 2013.

12. Budrys V. Klinikinè neurologija. Vilnius, 2009.

13. Sartorius N, Holt RJG, Moy N (ed.). Comorbidity of mental and physical disorders, Korger, 2015. https://doi.org/10.1159/isbn.978-3-318-02604-7

14. Daulatzai MA. Cerebral hypoperfusion and glucose hypometabolism: Key pathophysiological modulators promote neurodegeneration, cognitive impairment and Alzheimer's disease. Journal of Neuroscience Research 2016; 95(4):943-972. https://doi.org/10.1002/jnr.23777

15. Sadanand Sh, Balachandar R, Bharath S. Memory and executive functions in persons with 2 diabetes: a metaanalysis. Diabetes/ Metabolism Research and Reviews 2016; 32(2):132-142. https://doi.org/10.1002/dmrr.2664

16. Andro M, Le Squere P, Estvin S, Gentric A. Anaemia and cognitive performances in the elderly: a systematic review. European Journal of Neurology 2013; 20(9):1234-1240.

https://doi.org/10.1111/ene.12175

\section{PSYCHIATRY EVALUATION POSTMORTEM - CHAL- LENGE TO FORENSIC PSYCHIATRISTS V.Martinkienè}

Keywords: postmortem forensic psychiatry evaluation, testamentary capacity.

Summary

In the Lithuanian Forensic Psychiatry Service there have been 117 postmortem forensic psychiatry evaluations carried out during 2016-2018. The number of evaluations was different: there were 54 evaluations in 2016 and 28 in 2018. All postmortem forensic psychiatry evaluations were made with the purpose of evaluating a person's mental status during the confirmation of a legal contract/ testimony.
Forensic psychiatry evaluations always are a challenge for forensic psychiatrists because of retrospective attitude and often very limited data about a person's mental status. Usually there is only medical data from the family therapist about somatic diseases and some data from the person's private notes or documents. The task for a forensic psychiatrist in postmortem evaluation is to conduct an analysis on how somatic diseases and their complications impact a person's mental health and to compare this data to theoretical knowledge about the dynamic aspects of different diseases.

During 2016-2018 there were 117 evaluations in civil cases: 43 for men and 74 for women. There were 83 cases from persons living in cities and 34 cases of persons living in rural districts.

The average age has changed: in 2016, the average age for men, who signed the testimony, was 73 years and the average age for women was 80 years; in 2017 the average age for men was 69 years and the average age for women was 78; in 2018 the average age for men was 79 years, and for women - 89 years. There is an obvious difference - men sign the testimony about 10 years younger than women. This represents the overall difference in life expectancy between men and women in Lithuania.

Forensic psychiatry experts had a big challenge in postmortem evaluations because of the lack of psychiatric data. In 2016, 54 cases were evaluated and $72,2 \%(\mathrm{~N}=39)$ of these evaluations were made from data without the specific data about the psychiatric evaluation of a person's mental status being present. In 2017, 35 cases were evaluated and $80 \%(\mathrm{~N}=28)$ of them did not have psychiatric data. In 2018 - 28 cases and $82 \%(\mathrm{~N}=23)$ of them did not have psychiatric data. These figures show the difficulty of evaluation that must be carried out by a forensic psychiatrist in postmortem cases. In cases without psychiatric data, a lot of different somatic diseases and their complications which cause cognitive impact must be evaluated and this task demands a forensic psychiatrist to possess a profound knowledge in somatic and neurological diseases.

Correspondence to: vaiva.martinkiene@vtpt.lt

Gauta 2019-06-19 